\title{
Beroep op die skrif in die vorm van etiese standpunte, Deel 2: 'n Etiese verstaan van die vrou in die Bybel
}

\begin{abstract}
Author:
Adriaan L. Rheeder ${ }^{1}$

Affiliation:

${ }^{1}$ School for Ecclesiology, Potchefstroom Campus, North-West-University, South Africa

Correspondence to:

Riaan Rheeder

Email:

riaan.rheeder@nwu.ac.za

Postal address:

PO Box 62, Potchefstroom

2520, South Africa

Dates:

Received: 28 Sept. 2010

Accepted: 18 Jan. 2011

Published: 05 Dec. 2012

How to cite this article: Rheeder, A.L., 2012, 'Beroep op die skrif in die vorm van etiese standpunte, Deel 2: 'n Etiese verstaan van die vrou in die Bybel', In die Skriflig/ In Luce Verbi 46(2), 9 pages. http://dx.doi.org/10.4102/ ids.v46i2.65

Note:

Hierdie artikel dien ook as die tweede gedeeltelike repliek op D.C. Coetzee se skrywe in Woord en Daad naamlik 'Reaksie op "Die implikasie van die GKSA se 2009-sinodebesluit rakende die vrou in die regeeramp"', (Rheeder, A.L., Woord en Daad 49(409) Lente 2009, 34-36).
\end{abstract}

C 2012. The Authors. Licensee: AOSIS OpenJournals. This work is licensed under the Creative Commons Attribution License.
In 'n vorige artikel is beredeneer dat die grammaties-historiese metode van Skrifuitleg as kreatuurlike geskrif nie meer voldoende is vir alleengebruik in Skrifvertolking nie en dat dit met ander uitgangspunte aangevul moet word. In aansluiting by twee hermeneutiese uitgangspunte wat in 'n vorige artikel behandel is (Rheeder 2012), word in hierdie artikel 'n verdere drie hermeneutiese vertrekpunte bespreek, naamlik teenkultuur, nie-wetenskaplike skopus en moreel-etiese vertolking. Die teenkulturele vertrekpunt gaan uit van die oortuiging dat outentieke getuienis in die Skrif gevind word in dit wat verskil (afwyk) van die omliggende antieke kultuur, terwyl die nie-wetenskaplike skopus vertrekpunt uit gaan van die standpunt dat wetenskaplike (of empiriese) kennis in die Bybel buite die skopus of bedoeling van die Skrif staan. Die moreel-teologiese vertolking as vertrekpunt van die standpunt uitgaan dat 'n moreel-teologiese beoordeling van liefde die keuse tussen twee konflikterende, maar beide aanvaarbare, interpretasies moet begelei. Daar word tot die gevolgtrekking gekom dat 'n etiese verstaan van die posisie van die vrou beteken dat die vrou as gelykwaardig aan die man beskou en so behandel moet word, wat beteken dat die vrou, net soos die man, tot enige amp in die kerk toegelaat mag word.

Appeal to Scriptures in the formation of an ethical point of view: an ethical understanding of women in the Bible. In a previous article it was argued that the grammatical-historical method of Bible exposition was no longer sufficient as sole method and should be supplemented with other hermeneutical points of departure. Following the discussion of two hermeneutical points in a previous article (Rheeder 2012), this article will discuss three other hermeneutical points of departure, namely counterculture, non-scientific scope and moral-ethical interpretation. The counter-cultural point of departure is based on the belief that authentic witness in Scripture is found in that which is different (that which deviates) from the surrounding ancient culture, while a non-scientific scope starts from the view that scientific (or empirical) knowledge in the Bible is outside the scope or intent of Scripture. The point of departure of the moral-theological interpretation is the view that a moral-theological evaluation of love should inform the choice between two conflicting but mutually acceptable interpretations. It is concluded that an ethical understanding of women in the Bible means that women should be regarded and treated as equal to men, which leads to the further conclusion that all offices in the church should be open to women.

'Ons kommentaar op die Bybel is dikwels meer kommentaar op onsself as enigiets anders' (Van Niekerk, in Geloof sonder sekerhede)

\section{Inleiding}

In 'n voorafgaande artikel is aandag gegee aan die konteks van moderne hermeneutiek (in die GKSA), die gesag van die Skrif, asook twee hermeneutiese vertrekpunte wat in die vertolking van die Skrif met die oog op beoordeling van etiese probleme gebruik kan word (vgl. Rheeder 2012). Die huidige artikel moet in samehang met die vorige artikel gelees word en vorm in werklikheid 'n hermeneutiese en gedagte-eenheid.

In die eerste artikel is daarop gewys dat die Bybel as geïnspireerde geskrif 'n kreatuurlike boek is, wat beteken dat daar in die Skrif bepaalde menslike beperkinge of ideologieë voorkom (vlg. Rheeder 2012:bl. 2 van 9). Hierdie feit moet sorgvuldig by die vertolking van die Skrif in berekening gebring word. Hiermee kan die hermeneutiese vertrekpunte soos in die vorige en huidige artikel uiteengesit, help. Daar is verder ook erken dat die Bybel nie 'n teologiese boek is nie, wat beteken dat die vertolking van die Bybel nie beperk is tot wetenskaplike teoloë en sinodes nie, maar dat die belydenis van die duidelikheid van die Skrif daartoe moet lei dat individuele gelowiges die voorreg gegun word om veral in omstrede sake hulle eie oordeel oor die teks te vorm (vlg. Rheeder 2012:bl. 2 van 9). Die hermeneutiese vertrekpunte in die vorige en huidige artikel, saam met die gebruik van die grammaties-historiese metode, wil daarom ook die individuele gelowige help om in sy of haar vertolking van die Skrif tot 'n eie standpunt oor 'n etiese saak te kom. 
Verderhet die vorige artikel daarop gewys dat diegrammatieshistoriese metode wat in die verklaring van die Skrif gebruik word, nie kon bydra tot die oplos van interpretasieverskille nie. Die grammaties-historiese metode kon byvoorbeeld in dertig jaar nie in die Gereformeerde kerke (GKSA) bydra tot die verkryging van eenstemmigheid oor die vrou in die amp nie (vlg. Rheeder 2012:bl. 1 van 9). In die huidige artikel word die laaste drie van vyf hermeneutiese vertrekpunte verduidelik, sodat dit saam met die grammaties-historiese metode gebruik kan word om weer na die relevante tekste te kyk. Hierdie hermeneutiese vertrekpunte word ook aangebied as ' $n$ manier om die probleem van tydgerigtheid en tydgebondenheid te belig - iets wat die grammatieshistoriese metode nie altyd kon bereik nie.

Laastens moet net weer bevestig word dat hierdie hermeneutiese vertrekpunte voorgestel word as voorlopige hulp in die vertolking van die Skrif met die oog op die beoordeling van etiese probleme. Die hermeneutiese vertrekpunte word beredeneer en toegepas op 'n etiese verstaan van die posisie van die vrou in die Bybel.

\section{Drie hermeneutiese vertrekpunte ondersoek Inleidend}

Daar sal vervolgens aandag gegee word aan teenkultuur, nie-wetenskaplike skopus en moreel-etiese beoordeling as hermeneutiese vertrekpunte. Hierdie hermeneutiese vertrekpunte vind aansluiting by Cosgrove (2002) en Van der Walt (vgl. 2008, 2009) wat begin het deur bepaalde hermeneutiese vertrekpunte op die tafel te sit. Dit sluit voorts aan by twee hermeneutiese vertrekpunte, naamlik doelwit en analogie wat in die vorige artikel waarna hierbo verwys is, behandel is (vlg. Rheeder 2012:bl. 4 van 9).

\section{Teenkultuur as vertrekpunt}

Die derde hermeneutiese vertrekpunt gaan uit van die standpunt dat groter gewig aan teenkulturele uitsprake in die Skrif, uitsprake wat uitdrukking gee aan die stemme van die magtelose en gemarginaliseerde, verleen word as aan uitsprake wat net die bestaande omliggende kultuur navolg (Cosgrove 2002:90-91). Die reël van teenkultureel is van oortuiging dat outentieke getuienis in die Skrif gevind word in dit wat verskil (afwyk) van die omliggende antieke kultuur (Edwards 2003:135-136). Daarmee word nie gesê dat alles wat antieke kultuur is, verkeerd is en dat dit wat teenkultuur is, waar en reg is nie. Die teenkulturele hermeneutiese reël vorm 'n (stille) protes teen die heersende en dominante kultuur en wil waak teen ondeurdagte pogings waar die antieke kultuur sito-sito normgewend gemaak word (Snyman 2006:720). Ook Van Rensburg (2006:760) erken myns insiens hierdie reël as hy in verband met Paulus se uitsprake oor homoseksualiteit sê 'Paulus gaan juis dwars teen die samelewingskonvensie in.'

Hierdie reël werk soos volg: A en B ken gesag aan die Bybel toe, en $A$ verduidelik aan $B$ dat $X$ in die Bybel bloot die dominante kultuur van die antieke tyd reflekteer (dus tydgerig is). A verwag van B om af te lei dat min gewig aan $X$ as openbaringsgetuienis verleen moet word op grond van die volgende argumente: (1) goddelike openbaring is inherent anti-ideologies; (2) daarom is outentieke getuienis in die openbaring anti-ideologies; en (3) daarom is outentieke getuienis noodwendig in teenkulturele vorm. Anders gesê: wanneer $A$ aan $B$ verduidelik dat $Y$ teen die dominante antieke kultuur ingaan, verwag $A$ van $B$ om af te lei dat $Y$ vermoedelik groter gewig dra as $X$ (vgl. Cosgrove 2002:91-92).

Daar bestaan drie teologiese uitgangspunte wat hierdie hermeneutiese reël aantreklik maak:

- Die openbaring dat God teen alle ideologieë is, of soos Van Niekerk (2005:53) sê: 'Die Bybel is 'n magtige stuk ideologiekritiek: Dit staan dikwels haaks op baie van ons mees vertroude oortuigings.' God is nie teen kultuur per se nie, maar is teen daardie ideologiese kulturele instellings (as heersende waardestelsel in die gemeenskap, norme, institusies) wat die belange van persone in magsposisies bevorder op so ' $n$ manier dat dit skade berokken aan dié wat magteloos is (die Eksodus-motief en verlossing uit die ballingskap dien as voorbeelde; Mal 3:5; 2 Tess 1:6; Cosgrove 2002:91-92).

- Die Skrif leer dat God die bevryder of redder van die verdrukte of verontregte mens is (Ps 71:1-4; Ps 72:14; Jer 15:21; König 2001:143-146). Dat God hom as 'n reddende God openbaar, vorm 'n baie sterk getuienis in die Skrif (Berkhof 1985:93). Die konsep van epistemologiese privilegie (Bonhoeffer) van die verdrukte argumenteer dat spesiale gewig aan daardie stemme in die Skrif gegee word wat opstaan vir die sosiale magteloses en gemarginaliseerdes (Ps 35:10). Die fundering vir hierdie hermeneutiese reël word gevind in die feit dat Jesus Christus Homself vereenselwig het met die magteloses, die slawe en die uitgeworpenes in die samelewing (Luk 4:16-20; sondaars, belastinggaarders, vroue, gestremdes, kinders, nie-Jode en heidene), en dra daarom groter gewig as die kultureel-geaffilieerde stemme (Cosgrove 2002:91-93). Anders gesê, as Here en Koning eis God geregtigheid (Van Rensburg 2006:756-757) en daarom bied die Skrif bevrydende modelle aan (Van Wyk 2008:697).

- Alles in die Bybel kan nie gelyk gestel word met openbaring nie. Dit beteken dat alhoewel die Skrif onmisbaar is, dit nog steeds die onvolmaakte draer van openbaring is. As menslike getuienis dra die Bybel ook in sigself die taal van ideologie, diskriminasie, tydgerigtheid (vgl. Rheeder 2012:bl. 3 van 9; vgl. ook König 2001:168-169; vgl. Cosgrove 2002:91-92) of onderdrukkende modelle (Van Wyk 2008:697).

Holladay (1995:282) behandel die probleem van die status en rolle van die vrou in die Ou Testament en vra waarom die voor-ballingskapse profete wat hulle op so 'n kragtige manier uitgespreek het teen verkeerde tendense in die kultuur nooit die patriargale stelsel bevraagteken het nie. Die Bybel toon patriargale karaktertrekke (Snyman 2006:717), 'n feit wat ook deur die bekende gereformeerde etikus erken 
word wanneer hy sê: 'Wanneer ou, patriargale verhoudings uit hulle voeë bars, kan dit nie meer gestuit word dat vroue en kinders selfstandiger word, tot in die huwelikskeuse toe' (Douma 2009). Besondere voorbeelde hiervan word gevind in Eksodus 20:17, Genesis 19:5-8, Levitikus 27:1-3 en Johannes 8 (vgl. ook König 2001:168-170; Van Rensburg 2006:766-767; Breed, Van Rensburg \& Jordaan 2008:49-50; Van Niekerk 2005:51). Alle belangrike figure in die Bybel is mans: priesters, profete, konings, dissipels en Jesus self (König 2010:20). Die napraat van patriargie in die Bybel is waarskynlik die rede waarom Augustinus gemeen het dat 'n vrou se verhouding tot haar man soos dié van 'n slaaf tot sy of haar meester of soos dié van 'n siel tot God is (Snyman 2006:724). Holladay antwoord sy eie vraag deur daarop te wys dat die manlike en vroulike hiërargie, die patriargale stelsel, in die skeppingsorde gefundeer is (vgl. 1 Tim 2:11-14). Nieteenstaande hierdie feit word daar in Jeremia $31: 22$, 'n profesie van die nuwe skepping tog 'n teenkulturele uitspraak gevind waarin die rol van die vrou omgekeer word: 'Hoe lank sal jy bly aarsel, o afkerige dogter? Want die HERE het iets nuuts op die aarde geskape: Die vrou sal die man beskerm.' Holladay, soos aangehaal deur Keown, Scalise en Smothers (1998) verduidelik sy vertolking van hierdie teks soos volg:

Holladay accepts this interpretation plus one other, which he considers to be more important ... in the future that God will create, the female will assume the initiative and dominance that had been the male role.

Selfs Kroeze (1970) erken bogenoemde as hy soos volg oor vers 22 kommentaar lewer:

Die verandering, die oorgang is ook so ontstellend groot. Maar tog werklik waar. Dit is iets nuuts, wat die HERE bewerk! 'Die vrou sal die man beskerm!' Is dit nie die omgekeerde wêreld nie? Seker, dit is! Maar so nuut is die herskeppingswerk, die verlossingswerk van God! En al is dit nog so vreemd, omdat dit God is wat alle dinge nuut maak (Op 21:5), kan ons dit aanvaar. Eenmaal het die sonde die wêreld omgekeer. (bl. 70)

Jeremia se aanvaarding van die voorrang van die man teenoor die vrou is nie vreemd nie, maar wat wel verrassend is, is dat Jeremia iets profeteer wat nog nooit geprofeteer is nie, ' $n$ visie teen die bestaande patriargale kultuur. Hierdie uitspraak van Jeremia vorm 'n teenkulturele tema. Cosgrove (2002) stel dit soos volg:

... when Jeremiah challenges hierarchical gender codes, his witness thereby carries a mark of authenticity as true insight into the divine will, because it flows from the prophetic countercultural breakthrough that is most closely in tune with God's breakthrough in social history. (bl. 98-99)

So vorm die profeties bevrydende getuienis van die Bybel 'n algemene vorm en norm vir protes teen die patriargale stelsel of enige ander ideologie (Ruether 1982:54-66).

Op soortgelyke manier verwys Scholer (1987:407-420) na Galasiërs 3:28 ${ }^{1}$ as 'n profetiese teenkulturele uitspraak waarin die patriargale uitsprake en tekste in die Bybel gerelativeer word (Rust 2006:4). Teenkulturele en teen-patriargale uitsprake word ook gevind in uitsprake waar Paulus vroulike 1.'Daar is nie meer Jood of Griek nie, daar is nie meer slaaf of vryman nie, daar is nie meer man en vrou nie; want julle is almal een in Christus Jesus.' beheer erken (Rom 16:1, 2 en 7) en waar hy erken dat die vrou geestelike gawes beoefen (1 Kor 11:2-16; Cosgrove 2002:40 voetnota 49, 102-103). In 1 Korintiërs 7 word 'n besondere voorbeeld van teenkulturele uitsprake gevind waar Paulus aandui dat man en vrou mekaar nie seksuele omgang sonder wedersydse toestemming mag weier nie en dus as gelyke vennote optree (1 Kor 7:5, Meeks 1974:199-200; Rust 2006:10). ${ }^{2}$ Volgens König (2006:343) vorm laasgenoemde teenkulturele uitspraak 'n skokkende wederkerigheid waar die vrou nou saam besluit en dus 'n gelyke vennoot is (Van Rensburg 2006:767).

Meeks (1974:199-200) wys verder op die merkwaardige feit dat 1 Korintiërs 11:3 en 8, waar die manlike superioriteit in die skeppingsorde gefundeer word, deur die (paradoksale) teenkulturele gelykheidsuitsprake in vers 11-12 gerelativeer word. Die enigste manier om die kontradiksie tussen vers 8 en vers 12 by te lê, is deur groter gewig aan die teenkulturele

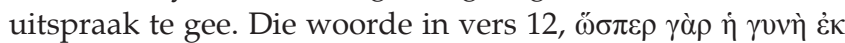

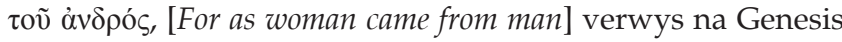
2:22 en dus na die skeppingsorde. Meeks (1974) poneer:

Paul emphasizes and reemphasizes in this letter, but even to the explicit statement in chapter 11 itself that 'in the Lord' the order of creation has been replaced by reciprocity (verses 11-12) ... Verses 11-12 state the contrary of verses 8-9: $\dot{\varepsilon} \mathrm{V}$ Kopi $\omega$ [the Lord] there is no man apart from woman or woman apart from man. Verse 12 , by reversing the language of verse $8 b$ and by adding the Allmachtsformel, (Tò $\delta \dot{\varepsilon ் ~ n a ́ v t a ~ \varepsilon ̇ K ~ t o v ̃ ~}$ $\theta \varepsilon \circ \tilde{)})$, relativizes the principle which has dominated the argument up to this point. (bl. 200-201)

In 1 Korintiërs 11:11-12 word dus 'n teenkulturele argument gevind wat die skeppingsorde as funderingsargument myns insiens relativeer, en daarom is König (2006:395-396) waarskynlik korrek as hy aanvoer 'dit bly maar 'n baie moeilike en riskante saak om uit die skepping self allerlei permanente strukture en gebruike af te lei' (vgl. ook Snyman 2006:720).

König (2006:396) wys daarop dat die konsekwente toepassing van die skeppingsorde-argument (ook genoem die anatomie-argument, vgl. Snyman 2006:725-726), beteken dat die huwelik en seks volgens Genesis 1:28 net op voorplanting afgestem is, en dat dit ook sou beteken dat twee ouer mense wat nie meer kinders kan verwek nie, nie met mekaar mag trou nie. Die argument maak ook die gebruik van voorbehoedmiddels onbybels. Die argument van die skeppingsorde vorm 'n sterk argument in Breed et al. (2008:69-76, 112, 142-143), en dien as argument om die oppergesag van die man te fundeer. ${ }^{3}$ Die retoriek van die natuurlike is baie sterk en word tot vandag toe as oortuigend beskou (Snyman 2006:725). ${ }^{4}$

2.'Rather, Paul affirms that a Christian marriage is to be two-sided, fully sexual, and mutually edifying' (Rust 2006:10).

3.'n Duidelike kontradiksie word ook gevind waar Breed et al. (2008:112-113) redeneer dat 1 Korintiërs 11:8-12 verwys na die skeppingsorde, maar aan die ander kant beweer dat 1 Korintiërs 11 nie die huwelik binne die gesigsveld het nie. Myns insiens het die Skrif altyd die huwelik in gedagte wanneer dit na die skeppingsorde
verwys en nie moeder-kind-verhouding soos Breed et al. (2008:113) beweer nie. Laasgenoemde word eintlik deur Breed et al. (2008:142) erken.

4.Wat Van Wyk (2008:700) van Totius sê, is myns insiens ook waar van die boek van Breed et al. (2008), naamlik: "n Mens kan tog nie enersyds beweer dat Christus die sentrum van die Godsopenbaring is, maar andersyds die Christologie in die politiek sentrum van die Godsopenbaring is, maar andersyds die Christologie in die politiek
onderspeel en slegs van ' $n$ skeppingsteologie gebruik maak nie.' Politiek kan met sosiale orde vervang word. 
Hierdie teenkulturele hermeneutiese reël vind ook sy diepste begronding in Christus as die finale openbaring (Heb 1:1). ${ }^{5}$ In aansluiting by Jeremia hierbo word in Spreuke 8:1-10 en Spreuke 9:1 gevind dat die wysheid wat vroulik is, die man leer en selfs tug:

Roep die Wysheid nie, en verhef die Verstandigheid nie haar stem nie? ${ }^{2}$ Op die top van die hoogtes langs die weg, op die kruispunt van die paaie staan $s y,{ }^{3}$ aan die kant van die poorte by die uitgang van die stad, by die ingang van die deure roep sy hardop: ${ }^{4} \mathrm{Ek}$ roep na julle, manne, en my stem is tot die mensekinders. ${ }^{5}$ Leer tog skranderheid verstaan, eenvoudiges, en dwase, leerverstandigheid verstaan. ${ }^{6} \mathrm{Hoor}$, want ek sal voortreflike dinge spreek, en my lippe gaan oop vir wat reg is. ${ }^{7}$ Want my verhemelte spreek waarheid, en goddeloosheid is vir my lippe ' $n$ gruwel. ${ }^{8} \mathrm{Al}$ die woorde van my mond is reg, daarin is niks wat slinks of vals is nie, ${ }^{9}$ hulle is almal duidelik vir die verstandige en reg vir die wat kennis gevind het. ${ }^{10} \mathrm{Neem}$ my tug aan, en nie silwer nie, en kennis liewer as uitgesoekte goud ... Die Wysheid het haar huis gebou, haar sewe pilare uitgekap.

Opvallend is Jesus se verhouding tot die vroulike wysheidsfiguur van Spreuke. Neem in ag dat daar na Jesus as die Wysheid (van ewigheid af volgens Spr 8:22 e.v.) verwys word (1 Kor 1:24, 30; Luk 11:496). Jesus word met wysheid wat vroulik is, vereenselwig en gelykgestel. Neem ook in aanmerking dat daar in Matteus 11:19 die volgende staan: 'Die Seun van die mens het gekom, Hy eet en drink, en hulle sê: Dáár is ' $n$ mens wat ' $n$ vraat en ' $n$ wynsuiper is, 'n vriend van tollenaars en sondaars.' Die wysheid (Jesus)

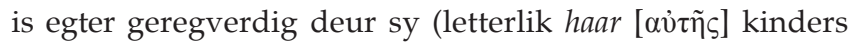
(Matt 11:2). Argumente wat waarskynlik ook ter sake is, is die feit dat God na die hele Israel verwys as sy seun (Hos 11:1) en dat die hele kerk die vrou van die Lam genoem kan word (Op 21:9; vgl. Snyman 2006:730-732). Bogenoemde beredenering wil eintlik sê dat seksualiteit of geslag nie vir Christus belangrik is nie en dat daar ewe maklik na Hom as manlik of vroulik verwys kan word. Geslag (of die ideologiese gebruik van geslag) speel geen rol in die Bybel nie (vgl. König 2001:166-168). Hierdie vertrekpunt word soos volg deur Cosgrove (2002) saamgevat:

Placed in their social context, these egalitarian impulses stand out as remarkable, courageous voices against what everyone else - most people within and without the church - took for granted ... it is remarkable, isn't it, that an egalitarian vision appears at all in the New Testament, given how deeply ingrained patriarchy was in the Greco-Roman world. (bl. 188)

Ten spyte van bogenoemde staan die Pous se uitspraak van 22 Januarie 1977 vas dat Christus 'n onbreekbare band tussen geslag en die ampte gestel het (Vorster 2008:143), en word daar selfs sover gegaan om te sê dat verlossing onlosmaaklik verbind is met die geslag van Christus ('Declaration inter insigniores on the question of admission of women to the ministerial priesthood' 1976):

Nevertheless, the incarnation of the Word took place according to the male sex: this is indeed a question of fact, and this fact, while not implying and alleged natural superiority of man over woman, cannot

5. Die feit dat die Skrif in die eerste plek daarop gemik is om harte te verander, geld vir die openbaring van die deurbraak van die koninkryk (Evangelies), waar Jesus in sy optrede toon watter plek geslagtelikheid by Hom speel (Breed et al. 2008:49).

6.Jesus, vgl. Matteus 23:34 be disassociated from the economy of salvation: it is indeed in harmony with the entirety of God's plan as God himself has revealed it, and of which the mystery of the Covenant is the nucleus.

Die voorafgaande argumente lei noodwendig tot die gevolgtrekking dat 'n mens nie anders kan as om van die gelykwaardigheid en gelykheid van man en vrou in alle opsigte te praat nie. Dit beteken nie dat patriargale gedeeltes in die Bybel niks te leer het nie; die punt is net dat die teenkulturele hermeneutiese reël die ideologiese karakter (man-vrou patriargale hiërargie) daarvan uitskakel ${ }^{7}$ en dat Rust (2006) daarom tereg kan sê:

Therefore, while Paul does call on wives to submit in some sense we can conclude that he does not thereby approve of the patriarchal structures as divinely ordained institutions and, in fact, works within them to subvert them. (bl. 12)

\section{Nie-wetenskaplike skopus as vertrekpunt}

Die vierde hermeneutiese vertrekpunt gaan uit van die standpunt dat wetenskaplike (of empiriese) kennis in die Bybel buite die skopus of bedoeling van die Skrif staan (Cosgrove 2002:116-117; Van Niekerk 2005:183). Die Bybel het ontstaan in 'n totaal voormoderne en daarom voorwetenskaplike wêreld waar die mees basiese insigte van die moderne wetenskap en geskiedskrywing volledig afwesig was. Daarom is bybelse tekste nie bedoel om wetenskaplike kennis oor te dra nie (Van Niekerk 2005:46-47). God gebruik die natuurwetenskaplike opvattings van die tyd waarin die Bybel ontstaan het om teologiese idees oor te dra (Vorster 2009:95-117). Van der Walt (2008:656, 660) wys ook daarop dat die meeste reformatoriese filosowe die Bybel as 'n voorwetenskaplike geloofsboek beskou en verklaar dat dit so gelees moet word. Hierdie reël het ontstaan as gevolg van die kerk se ontmoeting met moderne wetenskap. Moderne wetenskap is oortuig dat die wêreld nie 6000 jaar oud is nie en ook nie in ses dae van 24 uur elk geskape is nie (Vorster 2009:96). Die nie-wetenskaplike skopus as reël reageer teen aannames dat empiriese, premoderne wetenskaplike uitsprake in die Bybel as gesaghebbend beskou moet word (Cosgrove 2002:182) of, soos Vorster (2009:104) aanvoer, dat die wêreldbeeld van die Bybel nie normatief is nie, maar wel die goddelik-geïnspireerde teologie wat daarin vervat is.

In Matteus 6:22-23 word die oog die lamp van die liggaam genoem. Volgens die antiek-wetenskaplike verstaan van visie het die oog sy eie lig bevat of het lig van binne die oog ontstaan en na buite uitgestraal (Viljoen 2009:1-5). Moderne empiriese getuienis weerspreek die bybelse wetenskaplike inligting en daarom kan die kerk nie alle wetenskaplike empiriese inligting (ten grondslag van Matt 6) aanvaar nie. Indien wetenskaplik-empiriese getuienis deel van die skopus van die Skrif vorm, verwag dit iets van die moderne gelowige wat dit nie van die eerste gehoor van die kerugma verwag het nie. Volgens Bultmann (1961:3-4) is daar nie van die eerste gelowiges verwag om empiriese gegewens soos byvoorbeeld ' $n$ bybelse kosmologie (aarde is gevestig op

7.That "male and female" are included in Paul's list leads us to the following conclusions: that he saw gender as something which should no longer divide, that the structure of patriarchy has no place in the church, and that all this stands in the structure of patriarchy has no place in the church, and that all this stands in
sharp contrast to Philo's support for the well-defined and hostile distinctions sharp contrast to Philo's support for the
between men and women' (Rust 2006:4). 
pilare), ${ }^{8}$ of die teorie oor visie te glo nie (hulle vertroue daarin te plaas nie), omdat bepaalde wetenskaplike feite bloot as vanselfsprekend aanvaar is en 'n bepaalde kosmologie algemeen deel van die antieke lewe en wêreldbeskouing van die vroeë gelowiges was (vgl. ook Cosgrove 2002:129). Voeg hierby dat, indien die nie-wetenskaplike skopus van die Skrif verwerp word, dit sal beteken dat 'n konsekwente deurvoering van die standpunt daarin vervat, daartoe sal lei dat ' $n$ bybelse kosmologie aanvaar moet word, byvoorbeeld dat die aarde op pilare staan en dat die son om die aarde draai (Gen 1:6-8; Rig 9:12-13; Vorster 2009:99), en dat aanvaar sal moet word dat die oog lig uitstraal. In aansluiting met Bultmann se gedagte maak König (2010:31) die belangrike opmerking dat Israel nie 'n skeppingsgeloof (König se beklemtoning) gehad het nie maar 'n Skeppersgeloof (König se beklemtoning). Die bybelse geskrifte veronderstel die empiriese kennis en wêreldbeeld van die tyd en plek waarin die geskrifte ontstaan het (vgl. ook Van Niekerk 2005:46) en word op sigself nie aangebied as ' $n$ anakronistiese boek wat die empiriese kennis van die 21ste eeu antisipeer nie. Ook Augustinus is van mening dat waar die wetenskap met die Bybel verskil, die wetenskaplike kennis gerespekteer moet word, anders kan dit die kernboodskap van die Bybel in disrespek bring (Armstrong 2009:123). ${ }^{9}$

Ten grondslag van hierdie hermeneutiese vertrekpunt (inderdaad ten grondslag van al die hermeneutiese vertrekpunte in die artikel) is die erkenning dat die Skrif 'n bepaalde skopus het. Met die term skopus word verwys na die feit dat die Bybel 'n bepaalde breë boodskap het. König (2006:76) maak die opmerking dat dit in die Bybel nie oor klein, minder belangrike besonderhede gaan nie, maar oor die groot lyne (skopus) wat almal op Jesus uitloop. Breed et al. (2008:48) noem die skopus ook die kernmomente van die Skrif, waardeur geïmpliseer word dat sekere sake nie tot die kern van die boodskap van die Skrif behoort nie. Om dus te sê dat wetenskaplike kennis buite die skopus van die Skrif staan, beteken nie dat die Skrif nie wetenskaplike uitsprake maak nie; dit beteken net dat waar wetenskaplike uitsprake en aannames gevind word, dit nie tot die leerstellings, skopus of kern van die kerk behoort nie.

Die Skrif op sigself is 'n boek met ' $n$ bepaalde skopus (Verster 2009:806). Kortliks beteken dit dat die Skrif 'n paar sentrale doelwitte het wat regdeur die Skrif voorkom. Verskeie Nuwe

8.1 Samuel $2: 8$

9.'Usually, even a non-Christian knows something about the earth, the heavens, and the other elements of this world, about the motion and orbit of the stars and even their size and relative positions, about the predictable eclipses of the sun and moon, the cycles of the years and the seasons, about the kinds of animals, shrubs, stones, and so forth, and this knowledge he holds to as being certain from reason and experience...If they find a Christian mistaken in a field which they themselves know well and hear him maintaining his foolish opinions about our books, how are they going to believe those books in matters concerning the resurrection of the dead, the hope of eternal life, and the kingdom of heaven, when they think their pages are full of falsehoods on facts which they themselves have learnt from experience and the light of reason? ... Reckless and incompetent expounders of holy Scripture bring untold trouble and sorrow on their wiser brethren when they are caught in one of their mischievous false opinions and are taken to task by those who are not bound by the authority of our sacred books. For then, to defend their utterly foolish and obviously untrue statements, they will try to call upon Holy Scripture for proof and even recite from memory many passages which they think support their position, although "they understand neither what they say nor the things about which they make assertion"' (De Genesi ad Litteram, 1.19.39 in Augustinus 1982)
Testamentiese tekste verwys eksplisiet na die wese en doel van die Skrif: 2 Timoteus 3:16-17; 1 Korintiërs 10:11, Romeine 15:4 en Matteus 22:34-40. Uit hierdie Skrifgedeeltes is dit duidelik dat die Skrif 'n gefokusde doel het, naamlik die regte kennis van God, en hoe om reg of liefdevol teenoor God en jou naaste te lewe (Cosgrove 2002:125, 158-160; De Docrtrina Christiana 30-36 in Augustines 1886). Die Gees van God spreek in die Skrif deur prewetenskaplike konsepte van gewone antieke mense met die doel om hulle tot geestelike (geloofs-) waarheid en nie wetenskaplike waarheid te lei nie. Indien Matteus 22 inderdaad tot die skopus van Skrif behoort, beteken dit dat hierdie hermeneutiese reël deur Christus genormeer word (Cosgrove 2002:158).

Die reël van die nie-wetenskaplike skopus het ook besondere betekenis vir dit wat die Skrif leer oor die status en regte van die vrou of 'n etiese verstaan van die posisie van die vrou. Genesis 2-3 het nog altyd 'n beslissende rol in die kerk se leer oor geslagtelike verskille gespeel. 'n Besondere voorbeeld in die Nuwe Testament waarin die rol van man en vrou onderskei word deur 'n beroep op Genesis 2-3, word in 1 Timoteus 2:8-15 gevind. In die vers word dit duidelik gestel: 'Ek laat die vrou egter nie toe om onderrig te gee of oor die man te heers nie, maar sy moet haar stil hou.' Hierdie toepassing van die Genesis $2-3$ het van ongeveer die tweede tempel-periode voorgekom en daarna voortgeduur. Volgens die eerste-eeuse (wetenskaplike) siening van die vrou beteken dit dat die vrou beskuldig moet word vir die verdrywing uit die Paradys (verleiding, v. 14), en wel om die volgende rede: vroue is meer passievol ('n kragtige emosie, ook seksuele passie) as mans en omdat vrouens 'n swakker (of selfs geen) rasionele kapasiteit en beredeneringsvermoë besit, sukkel hulle geweldig om hulle passie te beheer (Rust 2006:3). ${ }^{10}$ Omdat vroue so intens passievol is en 'n gebrek aan rasionele selfbeheersing het, kan hulle makliker (seksueel en intellektueel) verlei word as die man (vgl. Baer 1970:14-45;11 Testament of Reuben 5:1-6:5, Cosgrove 2002:144; Rust 2006:312). Gevolglik moet vroue onder die kragtiger rasionele (intellektuele) beheer van die man geplaas word, sodat die sosiale orde binne die kerk op dié wyse beskerm kan word. In sy uitspraak wil Paulus die kerk teen die herhalende verleidingsgevaar van die vrou beskerm (vgl. 2 Kor 11:3; 2 Tim 3:5; Rust 2006).

Bogenoemde wetenskaplike aanname, naamlik dat die vrou rasioneel en intellektueel inferieur (swakker) is ten opsigte van die man, is eenvoudig nie wetenskaplik verdedigbaar nie, terwyl moderne wetenskap en ervaring die teendeel aandui. Daar is geen getuienis dat 'n vrou 'n swakker of kleiner rasionele vermoë as die man het nie. Verskeie studies het aangedui dat verskille tussen mans en vroue

10.So verwys Rust (2006:3) na'n tydgenoot van Paulus, die filosoof Philo: 'This is not a neutral distinction for Philo tells us earlier that the nous is patterned after God, and thus the woman, who has no part in the nous, is not fashioned in the image of God (Creation 69). Moreover, the irrationality of the female soul is frequently referenced as the cause for wickedness.'

11.Baer bespreek Philo se standpunt in diepte.

12.'It is because the woman lacked the rationality of the man that the serpent spoke first to her in the garden (Creation 165). While the man's soul is directed towards God, the woman's soul "clings to all that is born and perishes" (Philo On Special God, the woman's soul "Clings to all that is born and perishes" (Philo On Special
Laws 3.178). For Philo the female, sense-perceptible world is a threat to humanity's existence and an embodiment of all that went wrong in the garden' (Rust 2006:3). 
eerder vanuit die omgewing verklaar kan word as vanuit die genetika (Fausto-Sterling 1985:13-60), terwyl Cosgrove (2002:145) die opmerking maak: 'More important, there is far more statistical variation among individual males or females than between the sexes. Sex is therefore a useless predictor of cognitive abilities.' Alhoewel Timoteus nie sy wetenskaplike aannames aangaande die man en vrou uitspel nie, is dit tog nie onredelik om aan te neem dat hy wel sy skrywe fundeer in die diskriminerende eerste-eeuse verstaan van 'n inherente verskil tussen man en vrou nie. Die lees van 1 Timoteus 2:8-15 ooreenkomstig die nie-wetenskaplike skopus van Skrif noodsaak die verklaarder om nie die feitelik-wetenskaplike aanname ten grondslag van hierdie gedeelte te aanvaar nie, wat tot gevolg het dat die hele argument met betrekking tot die stilte en onderdanigheid van die vrou in duie stort.

Indien die hermeneutiese verwerping van die patriargale aannames in die teks van 1 Timoteus 2:8-15 aanvaar word, moet gevra word wat die getuienis van hierdie gedeelte dan is (vgl. 'Teenkultuur as vertrekpunt' in hierdie artikel). Daar is twee moontlikhede. Eerstens kan hierdie gedeelte die kerk leer dat die norm van versoening soos deur Christus bewerk, nie altyd deurwerk na die grondvlak in die kerk nie. Dit beteken dat die egalitaristiese ideaal soos uitgewys deur die nie-wetenskaplike hermeneutiese reël vir sommige gelowiges nooit ten volle sal realiseer nie, of dalk 'n tyd neem om deur ander gelowiges begryp te word (Johnson 1987:73-74). Tweedens leer hierdie gedeelte dat dit wat vir Eva geld, ook vir alle mans in die kerk geld, wat beteken dat mans sowel as vroue (veral dié in gesagsposisies) bedag moet wees teen verleiding op alle gebiede.

As die teenkulturele boodskap van geslagsgelykheid as 'n uitvoerbare sosiale ideaal gestel word (vgl. die hermeneutiese beginsel 'teenkultuur as vertrekpunt' hier bo), ontstaan die vraag waarom die Bybel dit nie aanmoedig dat die antieke samelewing (al is dit langsaam) in daardie rigting moet begin verander nie. Die rede is dat die Bybel 'n antieke samelewingsbeskouing veronderstel waarin die samelewing, soos byvoorbeeld gevind in Prediker 1:4-11, as sosiaal onveranderlik beskou word. Die onveranderlike verloop van die samelewing is isomorfies (ooreenstemmend) aan empiries waarneembare, eentonige, onveranderlike natuurverskynsels soos die sonsopkoms, wind en water. Dieselfde is ook waar van die Grieks-Romeinse samelewing:

The ancient understanding of history assumes flux but no fundamental structural social change' en 'Paul, for example, preaches that in Christ "there is neither ... lave or nor free, male nor female" (Gal 3:28), but he does not see this as a warrant for new social ethics. (Cosgrove 2002:138-139; vgl. ook Finley 1975:181; Meeks 1991:34-61)

In die lig van bogenoemde kan verstaan word waarom daar by Paulus geen revolusionêre oproep tot verandering van die samelewing gevind word nie (vgl. 1 Kor 7:20-21). Daar is nie geglo dat die samelewing deur menslike aktivisme kon verander nie. Wie dus redeneer dat Paulus (en die Bybel) nie sosiale veranderinge verkondig nie, aanvaar daarmee saam 'n antiek-wetenskaplike statiese samelewingsbeskouing. 'n
Voorbeeld van 'n uitspraak gegrond op die veronderstelde antiek-wetenskaplike samelewingsbeskouing in die Bybel, wat selfs ' $n$ beginsel genoem word, word gevind by Breed et al. (2008) wanneer hulle skryf:

Dit moet egter uitgemaak word wat die implikasie is van die beginsel dat die Skrif nie in die eerste plek samelewingstrukture en -konvensies verander nie, maar mense se harte. Die implikasie van hierdie beginsel moet nagegaan word vir die hermeneuse van die gegewe dat vroue nie oorweeg is by die aanwysing van 'n dissipel in Judas se plek of by die aanwysing van protodiakens nie. ${ }^{13}$ (bl. 40, 49-50, 66-67)

Wie dus uitgaan van die nie-wetenskaplike skopus van die Bybel, sal die statiese samelewingsbeskouing waarin Paulus optree, verwerp en begin opereer vanuit 'n moderne maatskappybeskouing dat die samelewing inderdaad kan verander. Cosgrove (2002:188) som die saak soos volg op:

This hope (Gal 3:28 - ALR) invites us, who live by different historical assumptions than the ancient Christians did, to embrace equality in die the light of our historical situation, which includes the knowledge that the world can change in fundamental ways through organized human agency.

\section{Moreel-teologiese vertolking as vertrekpunt}

Die vyfde hermeneutiese vertrekpunt gaan uit van die standpunt dat 'n moreel-teologiese beoordeling die keuse tussen twee konflikterende, maar albei aanvaarbare interpretasies moet begelei. 'The rule of moral-theological adjudication applies to competing interpretations of scripture, not competing parts of scripture' (Cosgrove 2002:195). Dit beteken nie dat ' $n$ teks nie betekenis het nie (Coetzee 2010:36), maar dat verskillende betekenis-moontlikhede ontstaan omdat die teks deur 'n proses van interpretasie gaan $^{14}$ (Van Rooy 2001:46; Van Rensburg 2006:747; Breed et al. 2008:66). Die studie van Breed et al. (2008:117-132) is 'n duidelike bewys dat dieselfde Skrifgedeelte meer as een moontlike interpretasie tot gevolg kan hê en dat hierdie verskille nie altyd eksegeties opgelos kan word nie (vgl. Rheeder 2012:bl 1 van 9; Van Rooy 2001:52). Telkens word in hierdie studie twee of meer verstaansmoontlikhede aan die leser voorgehou. Daar word selfs by geleentheid gesê: 'By die opweeg van hierdie twee standpunte word nie een van hulle ongeoorloof of eksegeties onhoudbaar bevind nie' (Breed et al. 2008:131). Uit laasgenoemde is duidelik dat 'n kerklike gemeenskap met 'n kerklike belydenis (rule of faith) soms nie genoegsaam is om interpretasieverskille op te los nie, juis omdat ' $n$ kerklike gemeenskap soms (onbewustelik) ideologies verbind is. Dit is so dat alle interpretasie subjektief is in die sin dat interpretasie in 'n mindere of meerdere mate op of deur die belange van die interpreteerder gerig is. Daarom is dit nodig dat moreel-teologiese oorwegings die keuse van 'n verklaring moet begelei. Die reël hou verband met die gedagte dat ' $n$ bepaalde interpretasieresultaat

13. Hierdie beginsel word dan ook as ' $n$ hermeneutiese vertrekpunt verstaan (vgl. Breed et al. 2008:45-64). Interessant genoeg is hierdie argument ook die amptelike standpunt van die Rooms-Katolieke Kerk: 'Jesus Christ did not call any women to become part of the Twelve' (Declaration inter insigniores on the question of to become part of the Twelve' (Declaration inter insignio
admission of women to the ministerial priesthood, 1976).

14.'When interpreters help meaning come into focus, they also multiply possibilities for meaning' (Cosgrove 2002:179). 
aan meer bekende leerstelling getoets moet word (Cosgrove 2002:185).

Hierdie reël erken die feit en beveel aan dat die keuse van een aanvaarbare interpretasie bo ' $n$ ander gelei moet word deur onafhanklike norme. Dit beteken dat 'n interpretasie deur of vanuit jou eie lewensvisie of etiese stelsel begelei word (Edwards 2003:136). Van der Walt (2009:15-18) wys daarop dat die nuwe hermeneutiek nie net meer klem op die teks lê nie, maar ook op die huidige leser van die teks (vgl. ook Cosgrove 2002; Van Niekerk 2005:47-53). Die konteks van die huidige leser het al 'n nie-ignoreerbare deel van die hermeunetiek geword (Vorster 2008:51). Die leser se eie omstandighede en veral sy eie lewensvisie (of filosofie) speel 'n beslissende rol daarin (Van Deventer 2010:4). 'n Lewensbeskoulike hermeneutiek word in hierdie hermeneutiese vertrekpunt as 'n liefdeshermeneutiek verstaan. Die gedagte dat die keuse van 'n aanvaarbare interpretasie deur substantiewe norme begelei moet word, is nie 'n nuwe verskynsel nie.

'In ons omgang met die Bybel kan die idees wat vervat is in die leer en lewe van Jesus, indien nie meer nie, dan ten minste net soveel klem begin kry as die tradisionele voorkeur wat Paulus se leerstellings in die geskiedenis van die kerk ontvang het,' skryf Van Niekerk (2005:100), en voer aan dat die liefde die hart van Jesus se boodskap vorm. In die Christelike geskiedenis word in die woorde van Jesus in Matteus 22:34-40 'n duidelike pleidooi vir die gebruik van liefde as 'n maatstaf in vertolking gevind. In Matteus 22:40 maak Jesus die uitspraak dat 'aan hierdie twee gebooie hang die hele wet en die profete'. Volgens Louw \& Nida (1989:778)

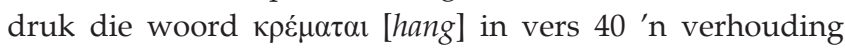
van afhanklikheid uit, waar een saak van 'n ander saak afhanklik is. Indien die uitspraak die eenheid en doel van die Skrif uiteensit, word aksiomaties daarmee saam die hermeneutiese reël gestel dat die hele Skrif geïnterpreteer (of gefiltreer) en toegepas moet word in ooreenstemming met die dubbele liefdesgebod (Donaldson 1995:689-709). In die lig van bogenoemde beredenering kan beweer word dat die liefdeskeuse as hermeneutiese reël deur die Skrif self en in besonder deur Christus gemaak word. Volgens Cosgrove (2002:158) is dit nie onredelik om te beweer dat Jesus in Matteus 12:1-14 inderdaad hierdie beginsel in die konfliksituasie toegepas het nie. Waarskynlik sluit Jesus aan by die Rabbynse hermeneutiese vertrekpunte van sy tyd, soos deur Armstrong (2009) verduidelik:

Any interpretation of scripture that bred hatred or disdain for others was illegitimate, while a good piece of exegesis sowed affection and dispelled discord. Anybody who studied scripture properly was full of love, explained Rabbi Meir; he 'loves the Divine Presence (Shekhinah) and all creatures, makes the Divine Presence glad and makes glad all creatures.' (bl. 84)

Bogenoemde gedagte word ook by die kerkvader Augustinus gevind. Augustinus (1886) erken dat sommige tekste in die Bybel meer as een wettige interpretasie moontlik maak (Doctrina Christiana 3.27-28 in Augustines 1886). In sy boek 1 van De Doctrina Christiana identifiseer Augustinus die doel van die Skrif as liefde vir God en liefde vir jou naaste
(De Doctrina Christiana Boek 1.35-37 in Augustines 1886). Volgens Augustinus moet die Skrif benader word met ' $n$ besef dat die doel van die Skrif gevind word in die beoefening van liefde (De Doctrina Christiana 1.40.44 in Augustines 1886). Die reël van liefde word in boek 3 as 'n verklaringsbeginsel gestel, en Augustinus verduidelik dat ' $n$ Skrifgedeelte gelees, bestudeer en vertolk moet word totdat die interpretasie daarvan met die beginsel van liefde verbind kan word (De Doctrina Christiana 3.15.23 in Augustines 1886; vgl. ook Cosgrove 2002:158-159; Armstrong 2009). ${ }^{15}$ Hy stel dit soos volg:

The tyranny of lust being thus overthrown, charity reigns through its supremely just laws of love to God for His own sake, and love to one's self and one's neighbor for God's sake. Accordingly, in regard to figurative expressions, a rule such as the following will be observed, to carefully turn over in our minds and meditate upon what we read till an interpretation be found that tends to establish the reign of love. Now, if when taken literally it at once gives a meaning of this kind, the expression is not to be considered figurative. (bl.123)

Die gebruik van liefde asook ander algemene teologiese konsepte as hermeneutiese begeleiding word ook in verskeie historiese dokumente van die Gereformeerde tradisie gevind. 'n Studie deur die Presbiteriaanse kerk in Amerika wys byvoorbeeld dat die Tweede Helvetiese konfessie (1566), die Sinode van Berne (1528) en die Skotse konfessie (1560), die hermeneutiese reël van liefde onderskryf, terwyl die Presbiteriaanse kerk self soos volg bely:

The fundamental expression of God's will is the two-fold commandment to love God and neighbor, and all interpretations are to be judged by the question whether they offer and support the love given and commanded by God. When interpretations do not meet this criterion, it must be asked whether the text has been used correctly in the light of the whole Scripture and its subject. Any interpretation of Scripture is wrong that separates or sets in opposition love for God and love for fellow human being, including both love expressed in individual relations and in human community (social justice). No interpretation of Scripture is correct that leads to or supports contempt for any individual or group of persons either within or outside of the church. Such results from the interpretation of Scripture plainly indicate that the rule of love has not been honored. This rule reminds us forcefully that as the rule of faith and life, Scripture is to be interpreted not just to discover what we are to think or what benefits we receive from God in Christ, but to discover how we are to live. (vgl. Presbyterian understanding and use of Holy Scripture 1983)

Hoe moet liefde in dié verband verstaan word? Gustafson (1970:440-441) wys op die gevaar dat liefde 'n breë begrip is wat verskillend toegepas kan word. Liefde kan hermeneuties soos volg verstaan word: Eerstens meen König (2006:301-302) dat die Bybel-interpreteerder, omdat hy ook God se beelddraer is, God se liefde in sy lewe en dus Bybeluitleg moet reflekteer. Bybel-interpretasie moet ook gerig wees op die beoefening van liefde teenoor jou naaste. God se liefde word op verskeie maniere verstaan, maar 'n besondere eienskap van God se liefde is dat dit prakties is, wat beteken dat God se liefde in bevryding realiseer (vgl. ook Berkhof 1985:93). Bevryding is uitgedeelde liefde. Bevryding is liefde net onder ' $n$ ander naam (Deut 4:37-38; 7:7-8; Jes 43; vgl. ook Gustafson 1970:446; Field 1995:10, 13). Christus, as voorbeeld van God se liefde (Joh 3:16), het die mensdom deur 15. The exegete must not leave a text until he could make it "establish the reign of charity", and if a literal understanding of any biblical passage seemed to teach hatred, the text must be interpreted allegorically and forced to preach love.' 
sy bloed van sonde en onderdrukking bevry (Heb 2:14-15). God het ons van verganklikheid bevry (Rom 8:23).

In die tweede plek kan verwys word na Van der Walt (2009), wat daarop wys dat God se wette, ook sy gebod om lief te hê, bedoel is om die mens sjaloom te laat ervaar:

Omdat God se wette bedoel is om die lewe in sy volle rykdom te beleef (Joh 10:10), kan allerlei soorte lyding 'n aanduiding wees (rooi ligte) dat 'n mens God se skeppingsordeninge verkeerd verstaan en positiveer. (Die kwessie van vroue in kerklike ampte in die GKSA sou weer as voorbeeld kon dien.) Groen ligte daarenteen is wanneer vreugde, vrede en heil (sjaloom) ervaar word. (bl. 24)

In samehang met veral die tweede punt verduidelik Van der Walt (2009:15-25) derdens sy lewensbeskoulike hermeneutiek ${ }^{16}$ (of liefdeshermeneutiek), waar hy die kriteria van openheid, ooreenstemming, gebalanseerdheid en leefbaarheid insluit:

- Met openheid word bedoel dat 'n lewensvisie (as hermeneutiek) nie die lewe in sy ryke verskeidenheid mag beknel nie, maar moet ontsluit (ontplooi). Bevorder die uitsluiting van vroue uit kerklike ampte byvoorbeeld werklik die ontsluiting van God se skepping?

- Ooreenstemming hou verband met die wedersydse wisselwerking tussen 'n lewensvisie en die werklikheid wat dit probeer weergee. Klop die werklikheid met my lewensvisie daaroor? Die gedagte word ook deur Snyman (2006:739) gesuggereer. Omgekeerd: klop my lewensvisie met die werklikheid waarin ek lewe? Maak dit sin of bots dit daarmee? Hoe verantwoord 'n mens jouself byvoorbeeld oor die feit dat jou lewensvisie nie vroue in kerklike ampte toelaat nie, terwyl hulle op ander terreine van die Suid-Afrikaanse samelewing leiersposisies mag beklee (vgl. ook Spangenberg 1998:110)?

- Om 'n werklikheidsvisie te wees, moet 'n lewensvisie op 'n gebalanseerde wyse tot uiting kom. Talle lewensvisies oorbeklemtoon egter een of ander aspek van die werklikheid. Manlike seksisme is 'n eeue oue voorbeeld hiervan.

- Die vraag is of die voorstanders van 'n lewensvisie ook bereid is om dit tot in sy finale konsekwensies uit te leef? In baie gevalle waar mense byvoorbeeld 'n seksistiese lewensvisie het, vind 'n mens dat hulle terugdeins vir die uiteindelike gevolge van hulle eie lewensvisie. Manlike chauvinisme kan byvoorbeeld afgewater word, sodat vroue ten minste as diakens aanvaarbaar is of vrouens wel katkisasie mag gee.

Wanneer bogenoemde toegepas word op die etiese verstaan van die posisie van die vrou (in die amp), kan tot die volgende gevolgtrekking gekom word:

- Wanneer twee botsende interpretasies oor die posisie van die vrou bestaan, moet die liefdesinterpretasie wat lei tot die bevryding van die vrou (uit patriargale strukture), dus sosiale geregtigheid teenoor die vrou, voorrang

16.Lewensbeskoulike hermeneutiek sou inderdaad as ' $n$ eie hermeneutiese reël bespreek kon word, soos Van der Walt (2009:23-26) doen. Aan die ander kant sou al vyf die voorgestelde hermeneutiese vertrekpunte as lewensbeskoulike hermeneutiese vertrekpunte beskou kon word. Snyman (2006:739) noem ook dat hermeneutiese vertrekpunte beskou kon word. Snyman (2006:739) noem ook dat
die Suid-Afrikaanse grondwet onteenseglik deel van die hermeneutiese raamwerk die Suid-Afrik geniet. 'Om vroue tot ampte toe te laat, bring die gebod dat ons God moet liefhê en ons naaste soos onsself tog nie in gedrang nie. Om die waarheid te sê, die toelating van vroue tot die ampte bevestig na regte dat ons erns maak met dié gebod,' skryf Spangenberg (1998:111). Dit beteken dat die vrou in alle opsigte gelyke behandeling moet ontvang. Ten minste kan lidmate die reg gegun word om self daaroor te oordeel (vgl. Rheeder 2012:bl. 2 van 9).

- Wanneer twee botsende interpretasies oor die posisie van die vrou bestaan, moet die interpretasie wat die meeste lyding vir die vrou veroorsaak, verwerp word. Dit beteken dat enige interpretasie van die Skrif wat die vrou van haar gelyke status aan die man beroof, verwerp moet word.

\section{Slot}

Hierdie artikel het die laaste drie van vyf hermeneutiese vertrekpunte geanaliseer. Die derde hermeneutiese vertrekpunt, die teenkulturele, is van oortuiging dat outentieke getuienis in die Skrif gevind word in dit wat verskil (afwyk) van die omliggende antieke kultuur. Daar is teenkulturele uitsprake in die Bybel wat daarop dui dat die patriargale tendens in die Skrif, waar die manlike en vroulike verhouding deur die man hiërargies bepaal is, nie meer geldig is nie. Dit beteken dat die man en vrou wel gelykwaardig tot enige amp in die kerk mag toetree. Die vierde hermeneutiese vertrekpunt gaan uit van die standpunt dat wetenskaplike (of empiriese) kennis in die Bybel buite die skopus of bedoeling van die Skrif staan. Die lees van 1 Timoteus 2:8-15 ooreenkomstig die nie-wetenskaplike skopus van die Skrif dwing die vertolker om die feitelik-wetenskaplike aannames ten opsigte van die vrou in 1 Timoteus 2 te verwerp, wat tot gevolg het dat die hele argument met betrekking tot die stilte en onderdanigheid van die vrou, in duie stort.

Die vyfde hermeneutiese vertrekpunt gaan uit van die standpunt dat 'n moreel-teologiese beoordeling, naamlik liefde, die keuse tussen twee konflikterende, maar beide aanvaarbare interpretasies moet begelei. Wanneer twee botsende interpretasies oor die posisie van die vrou bestaan (byvoorbeeld vir en teen die vrou in kerklike ampte), moet die liefdesinterpretasie wat tot die bevryding van die vrou (uit patriargale strukture) lei, en dus sosiale geregtigheid teenoor die vrou beteken, voorrang geniet.

Die bespreking van hierdie drie hermeneutiese vertrekpunte, saam met die bespreking van die grammaties-historiese metode, lei tot die gevolgtrekking dat die vrou wel, soos die man, tot die ampte van ouderling, predikant en professor toegelaat mag word.

\section{Erkenning Mededingende belange}

Die outeur verklaar dat hy geen finansiële of persoonlike verbintenis het met enige party wat hom nadelig kon beïnvloed in die skryf van hierdie artikel nie.

\section{Literatuurverwysings}

Armstrong, K., 2009, The Case for God, What religion really means, The Bodley Head, Londen. 
Augustinus, 1886, 'De Doctrina Christiana, A Select Library Of The Nicene And PostNicene Fathers Of The Christian Church', D.D., LI.D., in P. Schaff (red.), Volume II St. Augustin's: City Of God And Christian Doctrine, B. Eerdmans, Grand Rapids, St. Augustin's: City Of God And Christian Doctrine, B. Eerdmans, Grand Rapids,
Michigan, besigtig op 25 Junie 2010, by http://www.ccel.org/ccel/ schaff/ Michigan, besi
npnf102.v.html

Augustinus, 1982, De Genesi ad litteram, St. Augustine, The literal meaning of Genesis, vol. 1, transl. J.H. Taylor, in J. Quasten, W.J. Burghardt \& T.C. Lawler, Ancient Christian writers, vol. 41, Paulist Press, New York.

Baer, A.J., 1970, Philo's use of the categories male and female, E.J. Brill, Leiden.

Berkhof, H., 1985, Christelijk geloof, Een inleiding tot de geloofsleer, G.F. Callenbach, Nijkerk.

Breed, D.G., Van Rensburg, F.J. \& Jordaan, G.J.C., 2008, Man en vrou in die kerk, Geslagtelikheid en die besondere dienste, Potchefstroomse Teologiese Publikasies, Potchefstroom.

Bultmann, R., 1961, 'New Testament and mythology: The mythological element in the message of the New Testament and the problem of re-interpretation', in H.W. Bartsch (ed.), Kerugma and Myth, vol. 1, transl. R. Fuller, Harper \& Row, New York.

Coetzee, C.F.C., 2010, 'Belydenisgebondenheid in 'n postmoderne era', In die Skriflig 44(1), 27-45.

Cosgrove, C.H., 2002, Appealing to Scripture in moral debate, Five hermeneutical rules, Wm. B. Eerdmans, Grand Rapids.

'Declaration inter insigniores on the question of admission of women to the ministerial priesthood', 1976, Sacred congregation for the doctrine of the faith, besigtig op 21 September 2010, by http://www.vatican.va/roman curia/congregations/cfaith/ documents/rc con cfaith doc 19761015 inter-insigniores en.html

Donaldson, T.L., 1995, 'The law that hangs (Matthew 22:40): Rabbinic formulation and Matthean social world', Catholic Biblical Quarterly 57, 689-709.

Douma, J., 2009, Woord en Wandel, besigtig op 28 Desember 2010, by http://www. christelikebiblioteek.co.za/uploads/files_versions/1382_8Ylhxaae.pdf3

Edwards, R.M., 2003, 'Appealing to scripture in moral debate: Five hermeneutical rules', Review of Biblical Literature 5, 134-137.

Fausto-Sterling, A., 1985, Myths of Gender: Biological theories about woman and men, Basic Books, New York.

Field, D.H., 1995, 'Love', in D.J. Atkinson \& D.H. Field (eds.), New dictionary of Christian ethics and pastoral theology, pp. 9-15, Intervarsity Press, Downers Grove, IL.

Finley, M.I., 1975, 'Utopianism ancient and modern' in M.I. Finley, The use and abuse of history, Viking Press, New York.

Gustafson, J.M., 1970, 'The place of Scripture in Christian ethics: A methodological study', Interpretation 24, 430-455.

Holladay, W.L., 1995, Long ago God spoke: How Christians may hear the Old Testament today, Augsburg Fortress Press, MN.

Keown, G.L., Scalise, P.J. \& Smothers, T.G., 1998, 'Word Biblical Commentary, vol. 27: Jeremiah 26-52' in B.M. Metzger, D.A. Hubbard \& G.W. Barker, Logos Bybel Biblioteek, SA deel A, Word Books, Dallas, TX [CD-ROM].

König, A., 2001, Die helfte is my nooit oor Jesus vertel nie, 'n Nuwe kyk op die een wat jou lewe verander, Lux Verbi. BM, Wellington.

König, A., 2006, Die groot geloofswoordeboek, Meer as 500 kernwoorde van die Christelike geloof maklik gemaak, Christelike Uitgewersmaatskappy (CUM), Vereeniging.
König, A., 2010, Wat kan ek glo? Ondersoek en verryk jou geloof, Christelike Uitgewersmaatskappy (CUM), Vereeniging.

Kroeze, J.H., 1970, Die Prediker uit Anatot, Gedagtes en gedigte uit die boek Jeremia, Potchefstroom Herald, Pretoria.

Louw, J.P. \& Nida, E.A., 1989, Greek-English lexicon of the New Testament based on semantic domains, National Book Printers, Kaapstad.

Meeks, W.A., 1974, 'The image of the androgyny: Some uses of a symbol in earliest Christianity', History of Religions 13(3), 165-208.

Meeks, W.A., 1991, The moral world of the first Christians, Westminster Press, Philadelphia.

Presbyterian understanding and use of holy scripture, 1983, 'Position Statement Adopted by the 123rd General Assembly (1983) of the Presbyterian Church in the United States', Louisville, KY, The office of the General Assembly, 1999, besigtig op 25 Junie 2010, by http://www.pcusa.org/oga/publications/scripture-use.pdf

Rheeder, A.L., 2012, 'Beroep op die skrif in die vorming van etiese uitsprake: 'n Etiese verstaan van die vrou in die Bybel', In die Skriflig/In Luce Verbi 46(2) Art. \#58, 9 bladsye.

Ruether, R.R., 1982, 'Feminism and patriarchal religion: Principles of ideological critique of the Bible', Journal for study of the Old Testament 22, 54-66.

Rust, J., 2006, Women in 1st century Mediterranean culture: A comparison between Philo of Alexandria and Paul of Tarsus, besigtig op 03 September 2010, by http:// www.rustyparts.com/wp/wp-content/uploads/philo_paul_women.pdf

Scholer, D.M., 1987, 'Feminist hermeneutics and evangelical Biblical interpretation', Journal of the Evangelical Theological Society 30, 407-420.

Snyman, G., 2006, 'Homoseksualiteit en tydgerigtheid: 'n etiek van Bybellees?', In die Skriflig 40(4), 715-744.

Spangenberg, I., 1998, Perspektiewe op die Bybel, God se Woord in mensetaal, J.L. Van Schaik, Pretoria.

Van der Walt, B.J., 2008, 'Probleme rondom die Bybel in die gereformeerde teologie: besinning vanuit ' $n$ Christelike filosofie', In die Skriflig 4(4), 635-663.

Van der Walt, B.J., 2009, 'Probleme rondom die Bybel in die gereformeerde teologie: Besinning vanuit ' $n$ Christelike filosofie', In die Skriflig 43(1), 1-29.

Van Deventer, H.J.M., 2010, 'Eerder anders as elders: Gerrie Snyman se bydrae in die konteks van die Gereformeerde teologie', Verbum et Ecclesia 31(1), 1-6.

Van Niekerk, A.A., 2005, Geloof sonder sekerhede: Besinning vir eietydse gelowiges, Lux Verbi. BM, Wellington.

Van Rensburg, F.J., 2006, 'Die tydgerigtheid van die Bybel en die etiek van Bybellees: Respons op die artikel van Gerrie Snyman', In die Skriflig 40(4), 745-769.

Van Rooy, H.F., 2001, 'Per bonam consequentiam: Die status van eksegetiese afleidings', In die Skriflig 35(1), 45-59.

Van Wyk, J.H., 2008, 'Oor die Bybel, Bybellees en etiek: In gesprek met Gerrie Snyman', In die Skriflig 42(4), 685-707.

Viljoen, F.P., 2009, 'A contextualised reading of Matthew 6:22-23: "your eye is the lamp of your body"', HTS Teologiese Studies/Theological Studies 65(1), 1-5.

Verster, P., 2009, 'Skrifberoep en die hantering daarvan in die sending', In die Skriflig 43(3), 793-807.

Vorster, J.M., 2008, 'The challenge of contemporary religious fundamentalism', in C. Landman (ed.), Studia Historiae Ecclesiasticae Book Series, Church History Society of South Africa, Pretoria.

Vorster, N., 2009, 'Die teologies-polemiese gerigtheid van Genesis 1-3: Implikasies vir die gereformeerde leer oor die erfsonde', In die Skriflig 43(1), 95-117. 